\title{
Universiteit
}

Leiden

The Netherlands

\section{The square-planar cytotoxic [cUii(PYRIMOL)cL] complex acts as an efficient DNA cleaver without reductant}

Maheswari, P.U.; Roy, S.; Dulk, H. den; Barends, S.; Wezel, G.P. van; Kozlevcar, B.; ... ; Reedijk, J.

\section{Citation}

Maheswari, P. U., Roy, S., Dulk, H. den, Barends, S., Wezel, G. P. van, Kozlevcar, B., ... Reedijk, J. (2006). The square-planar cytotoxic [cUii(PYRIMOL)cL] complex acts as an efficient DNA cleaver without reductant. Journal Of The American Chemical Society, 128(3), 710-711. doi:10.1021/ja056970+

Version: $\quad$ Publisher's Version

License: $\quad$ Licensed under Article 25fa Copyright Act/Law (Amendment Taverne)

Downloaded from: https://hdl.handle.net/1887/3217439

Note: To cite this publication please use the final published version (if applicable). 


\title{
The Square-Planar Cytotoxic [Cu"(pyrimol)Cl] Complex Acts as an Efficient DNA Cleaver without Reductant
}

\author{
Palanisamy Uma Maheswari, ${ }^{\dagger}$ Sudeshna Roy,${ }^{\dagger}$ Hans den Dulk, ${ }^{\dagger}$ Sharief Barends,${ }^{\dagger}$ Gilles van Wezel, ${ }^{\dagger}$ \\ Bojan Kozlevčar, ${ }^{\ddagger}$ Patrick Gamez, ${ }^{\dagger}$ and Jan Reedijk ${ }^{\star}, \dagger$ \\ Leiden Institute of Chemistry, Gorlaeus Laboratories, Leiden University, P.O. Box 9502, 2300 RA Leiden, \\ The Netherlands, and Faculty of Chemistry and Chemical Technology, University of Ljubljana, Aškerčeva 5, \\ 1001 Ljubljana, P.O. Box 537, Slovenia
}

Received October 19, 2005; E-mail: reedijk@chem.leidenuniv.nl

The biomimetic approach of in vitro DNA damaging using "chemical nucleases" is a topic of major interest for elucidating the genetic mechanisms of the natural enzymes involved in DNA scission, repair, and signal transduction. ${ }^{1-4}$ Other potential applications of these synthetic nucleases include their use as antibiotic or chemotherapeutic drugs, which could act against tumors by blocking gene expression, with or without sequence specificity. ${ }^{5,6}$ Since the discovery of the first chemical nuclease, ${ }^{7}$ a number of transitionmetal complexes have been reported as synthetic nucleases with or without co-reactants. ${ }^{8}$ The transition-metal-mediated scission of the DNA strands may be oxidative and/or hydrolytic depending on recognition elements in the ligand that could interact with DNA. ${ }^{9,10}$

It is known ${ }^{11,12}$ that the marine products, tambjamine $\mathrm{E}$ and prodigiosin, can be oxidized to $\pi$-radical cations in the presence of $\mathrm{Cu}^{\mathrm{II}}$ ions. The resulting species efficiently cleave DNA oxidatively without any external reductant ${ }^{11,12}$ and also show promising cytotoxic effects on HL 60 (leukemia) cancer cells. ${ }^{13}$

The DNA-cleaving abilities and the cytotoxic effects of the title complex, which is highly soluble in water, are reported below. The copper complex is easily obtained from the readily available ligand Hpyramol, ${ }^{14}$ which is dehydrogenated to pyrimol upon coordination to the metal center (Figures 1, and S1 and S2). ${ }^{15,16}$

A $50 \mathrm{nM}$ solution of the planar complex ${ }^{17}$ effectively cleaves ФX174 supercoiled DNA ( $80 \mu \mathrm{M}$, in base pairs) to $73 \%$ of its relaxed form, after an incubation time of $20 \mathrm{~min}$, at $37{ }^{\circ} \mathrm{C}$ in the presence of ascorbic acid ( $5 \mu \mathrm{M})$. Without added reductant, as much as $75 \%$ of the relaxed form is obtained after the same incubation time at $37^{\circ} \mathrm{C}$, with a $10 \mu \mathrm{M}$ solution of the complex (Figure S3). Different metal salts, such as $\mathrm{MnCl}_{2}, \mathrm{FeCl}_{2}, \mathrm{CoCl}_{2}$, and $\mathrm{NiCl}_{2}$, have been used under similar conditions without reductant, and they all resulted in nonactive systems (Figure S4). The copper-mediated cleavage of DNA, both in the absence and in the presence of a reductant, is purely oxidative since the relaxed/linear reaction products are not re-ligated by the enzyme T4 ligase (Figure S5).

Experiments with a variety of radical scavengers point toward the involvement of a hydroxyl radical as the active species for the DNA cleavage, with added ascorbic acid as a reductant, since DMSO and ethanol, typical of $\mathrm{OH}^{\bullet}$ scavengers, inhibit the cleaving ability of the complex (Figure S6). ${ }^{18}$ Surprisingly, the DNA cleavage in the absence of reductant is not inhibited by any of the used radical scavengers and is even more efficient under an argon atmosphere compared to air (Figure S7). ${ }^{19}$ Such a catalytic oxidative cleavage in the presence of a redox-active metal, such as copper, is likely ${ }^{18}$ to occur when some radical species are produced. However, the treatment of $[\mathrm{Cu}($ pyrimol $) \mathrm{Cl}]\left(\mathrm{H}_{2} \mathrm{O}\right)$ with the radical trap DMPO

\footnotetext{
$\dagger$ Leiden University.

¥ University of Ljubljana.
}

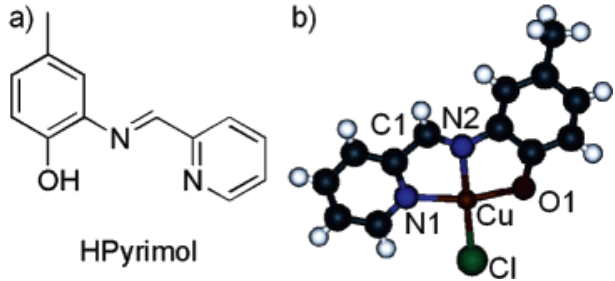

Figure 1. (a) Hpyrimol ligand and (b) molecular structure of $\left[\mathrm{Cu}^{\mathrm{II}}\right.$ (pyrimol)$\mathrm{Cl}]$.

( $N, N$-dimethylpyrrolidine- $N$-oxide) in water does not provide any evidence for radical formation under ambient conditions even after 24 h. Finally, both distamycin and an excess of sodium chloride have no inhibitory effects on the cleaving ability of the complex when no reductant is added (Figure S7).

Under the conditions described in the Supporting information, the supercoiled DNA is converted to the relaxed form and, subsequently, to the linear form in a stepwise manner, without any evidence for a direct double-strand DNA cleavage (Figure S8). Agarose gel experiments under denaturing conditions also support the above conclusion (Figure S9). However, the reaction of a stoichiometric amount of the copper complex $(40 \mu \mathrm{M})$ with plasmid DNA (40 $\mu \mathrm{M}$ in base pairs) immediately yields the linear form III of DNA resulting from a double-strand scission, after an incubation time of $15 \mathrm{~min}$, exhibiting a concentration-dependent catalytic activity (Figures S10 and S11). Time-course experiments in the presence of a $20 \mu \mathrm{M}$ solution of complex and $80 \mu \mathrm{M}$ (in base pairs) solution of supercoiled DNA reveal pseudo-first-order kinetics, as illustrated in Figure 2a,b. The DNA cleavage is followed under "true Michaelis-Menten" kinetic conditions, ${ }^{20}$ using a constant catalyst concentration $(20 \mu \mathrm{M})$ and varying the substrate concentration (from 60 to $160 \mu \mathrm{M}$, in base pairs) with an incubation period of $20 \mathrm{~min}$ (Figure 2c; the incubation period is restricted to $20 \mathrm{~min}$ to limit the formation of form III and to allow the calculation of the kinetic parameters), ${ }^{21}$ which gives a $k_{\text {cat }}$ value of $0.063 \mathrm{~min}^{-1}$ with a DNA cleavage rate enhancement of as much as $1.0 \times 10^{8}$ times over the undamaged ds-DNA (Figure $2 \mathrm{~b}$ ). From the $k_{\text {cat }}$ value, a short half-life time of $11 \mathrm{~min}$ is determined for the supercoiled DNA, with a complex concentration of $20 \mu \mathrm{M}$. These kinetic parameters confirm the very high efficiency of this simple copper complex toward DNA damage.

High-resolution analysis of the degradation pattern of linear 392 and 54 bp DNA fragments $\left(5^{\prime}-{ }^{32} \mathrm{P}\right.$-end-labeled at one side; see Figure S12 A,B) in all cases clearly demonstrates the lack of discrete cleavage products. Thus the copper complex degrades the DNA in a nonspecific manner, most likely attacking the DNA in multiple positions instead of by a uniform, single cleavage event. This 
(a)

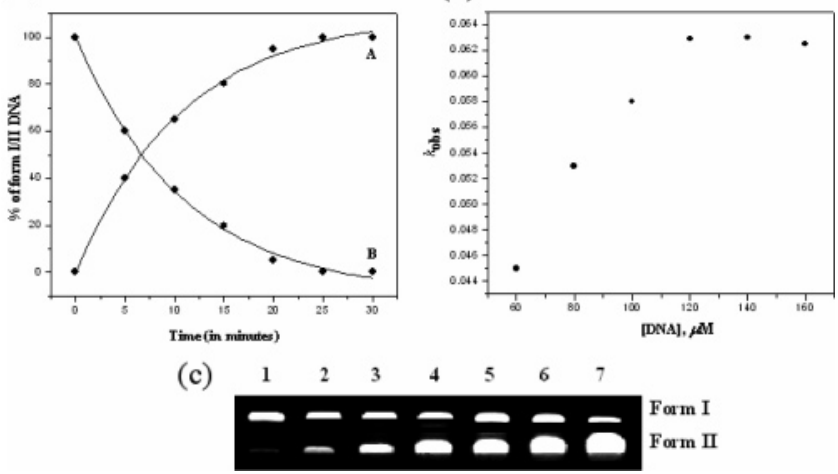

Figure 2. (a) Time-course experiments of DNA cleavage $(80 \mu \mathrm{M}$ of supercoiled DNA (in base pairs) $+20 \mu \mathrm{M}$ of copper complex) over a period of $30 \mathrm{~min}$. Plot of the increase in form II with time (A), and plot of the decrease in form I with time (B). (b) Plot of the $k_{\text {obs }}$ versus the concentration of DNA from true Michaelis-Menten kinetic studies; the highest $k_{\text {cat }}$ value obtained is $0.063 \mathrm{~min}^{-1}$. (c) Saturation kinetics of the cleavage of $\Phi \times 174$ supercoiled plasmid DNA using $20 \mu \mathrm{M}$ copper complex. Various amounts of plasmid were reacted with a constant concentration of the complex for $20 \mathrm{~min}$ at $37^{\circ} \mathrm{C}$ in a phosphate buffer at $\mathrm{pH}$ 7.2. Lane 1: pure supercoiled DNA $(60 \mu \mathrm{M})$. Lane 2: $60 \mu \mathrm{M}$ DNA $+20 \mu \mathrm{M}$ complex. Lane 3: $80 \mu \mathrm{M}$ DNA $+20 \mu \mathrm{M}$ complex. Lane 4: $100 \mu \mathrm{M}$ DNA $+20 \mu \mathrm{M}$ complex. Lane 5: $120 \mu \mathrm{M}$ DNA $+20 \mu \mathrm{M}$ complex. Lane 6: $140 \mu \mathrm{M}$ DNA $+20 \mu \mathrm{M}$ complex. Lane 7: $160 \mu \mathrm{M}$ DNA $+20 \mu \mathrm{M}$ complex.

Table 1. In Vitro Cytotoxicity Assays for the Copper Complex and Cisplatin for Cancer Cell Lines

\begin{tabular}{crrrrr}
\hline & \multicolumn{2}{c}{$[\mathrm{Cu}($ pyrimol)Cl] } & & \multicolumn{2}{c}{ Cisplatin } \\
\cline { 2 - 3 } \cline { 5 - 6 } cell lines & \multicolumn{1}{c}{$\mathrm{IC}_{50^{a}}$} & \multicolumn{1}{c}{$\mathrm{RF}^{b}$} & & \multicolumn{1}{c}{$\mathrm{IC}_{50}{ }^{\mathrm{a}}$} & $\mathrm{RF}^{b}$ \\
\hline L1210 (1) & $3.6 \pm 0.2$ & $2.9 \pm 0.2$ & & $2.3 \pm 0.3$ & $6.2 \pm 0.2$ \\
L1210 (2) & $10.3 \pm 0.3$ & & & $14.2 \pm 0.2$ & \\
A2780 (3) & $3.4 \pm 0.2$ & $2.5 \pm 0.4$ & & $2.3 \pm 0.2$ & $3.3 \pm 0.5$ \\
A2780 (4) & $8.3 \pm 0.6$ & & & $7.5 \pm 0.2$ & \\
\hline
\end{tabular}

${ }^{a} \mathrm{IC}_{50}=$ concentration of drug required to eradicate $50 \%$ of the cancer cells (in $\mu \mathrm{M}) .{ }^{b} \mathrm{RF}=$ relative ratios of $\mathrm{IC}_{50}$ values in both the cisplatinresistant and the sensitive cell lines.

reinforces the lack of sequence or site selectivity in the DNA cleavage by the copper complex (see Supporting Information pp 12-15).

The cytotoxicities of $[\mathrm{Cu}($ pyrimol $) \mathrm{Cl}]$ and cisplatin, under similar conditions, on L1210 murine leukemia cancer cell lines, ${ }^{22,23}$ which are sensitive (1) and resistant (2) to cisplatin, and A2780 human ovarian carcinoma cell lines, which are sensitive (3) and resistant to cisplatin (4), are summarized in Table 1.

The $\mathrm{IC}_{50}$ values for the cell lines $\mathbf{1}, \mathbf{3}$, and $\mathbf{4}$ are in the range of those observed with cisplatin. For the L1210 cancer cell lines 2, the copper complex is more active than cisplatin. These results are promising for a potential clinical application since the activity of this labile copper complex is comparable to that of the platinum drug. Interestingly, the copper complex has overcome the crossresistance of cisplatin that is observed for both the cancer cell lines that are resistant to cisplatin, as expressed by the resistance factors, $\mathrm{RF}$, which are low for the copper complex compared to cisplatin.

All of the above experiments strongly indicate a "self-activating" mechanism, most likely initiated by the intercalation of the highly planar conjugated copper complex between the base pairs. Previous reports on similar systems have proposed the reduction of $\mathrm{Cu}^{2+}$ to $\mathrm{Cu}^{+}$, or its oxidation to $\mathrm{Cu}^{3+}$, followed by the activation of $\mathrm{O}_{2}$ or $\mathrm{H}_{2} \mathrm{O}_{2},{ }^{24-26}$ producing reactive oxygen species, which is the ultimate source for DNA cleavage. In the present study, evidence for $\mathrm{Cu}^{+}$ or any diffusible radical could not be observed. The irreversible oxidation of DNA even in the presence of an excess of $\mathrm{NaCl}$, distamycin, or under argon rules out the need of dioxygen and a simple electrostatic interaction of the copper complex with DNA. It could be expected that the solvent $\mathrm{H}_{2} \mathrm{O}$ removes the electrons from the reduced copper, which presumably oxidizes the DNA again. Detailed mechanistic investigations on this unusual and outstanding copper-mediated DNA cleavage with related ligands bearing different substituents on the aromatic rings, such as $\mathrm{NO}_{2}$, $\mathrm{CH}_{3} \mathrm{O}$, or $\mathrm{Cl}$, are currently in progress.

Acknowledgment. Financial support from COST Action D21/ 003/01, the Dutch National Research School Combination Catalysis (HRSMC/NIOK), and EET are thankfully acknowledged. Prof. Jaap Brouwer and Mrs. Martina de Ruijter are thanked for their kind help extended to us in the biological experiments.

Supporting Information Available: Crystallographic data for [Cu(pyrimol) $\mathrm{Cl}]\left(\mathrm{H}_{2} \mathrm{O}\right.$ ), experimental procedures, and gel electrophoreses for the several DNA cleavage and cytotoxic studies. This material is available free of charge via the Internet at http://pubs.acs.org.

\section{References}

(1) Mancin, F.; Scrimin, P.; Tecilla, P.; Tonellato, U. Chem. Commun. 2005, $2540-2548$.

(2) Sreedhara, A.; Cowan, J. A. J. Biol. Inorg. Chem. 2001, 6, 337-347.

(3) Cowan, J. A. Curr. Opin. Chem. Biol. 2001, 5, 634-642.

(4) Liu, C.; Wang, M.; Zhang, T.; Sun, H. Coord. Chem. Rev. 2004, 248 , $147-168$.

(5) Williams, R. P.; Hearn, W. R. Antibiotics 1967, 2, 410.

(6) Yamamoto, C.; Takemoto, H.; Kuno, K.; Yamamoto, D.; Tsubura, A.; Kamata, K.; Hirata, H.; Yamamoto, A.; Kano, H.; Seki, T.; Inoue, K. Hepatology 1999, 30, 894-902.

(7) Sigman, D. S.; Graham, D. R.; Daurora, V.; Stern, A. M. J. Biol. Chem. 1979, 254, 2269-2272.

(8) Sigman, D. S.; Landgraf, R.; Perrin, D. M.; Pearson, L. Met. Ions Biol. Syst. 1996, 33, 485-513.

(9) Thederahn, T. B.; Kuwabara, M. D.; Larsen, T. A.; Sigman, D. S. J. Am. Chem. Soc. 1989, 111, 4941-4946.

(10) Deck, K. M.; Tseng, T. A.; Burstyn, J. N. Inorg. Chem. 2002, 41, 669677

(11) Borah, S.; Melvin, M. S.; Lindquist, N.; Manderville, R. A. J. Am. Chem Soc. 1998, 120, 4557-4562.

(12) Melvin, M. S.; Tomlinson, J. T.; Saluta, G. R.; Kucera, G. L.; Lindquist, N.; Manderville, R. A. J. Am. Chem. Soc. 2000, 122, 6333-6334.

(13) Melvin, M. S.; Wooton, K. E.; Rich, C. C.; Saluta, G. R.; Kucera, G. L.; Lindquist, N.; Manderville, R. A. J. Inorg. Biochem. 2001, 87, 129-135.

(14) Wong, Y. L.; Ng, D. K. P.; Lee, H. K. Inorg. Chem. 2002, 41, 52765285 .

(15) Pachón, L. D.; Golobic, A.; Kozlevcar, B.; Gamez, P.; Kooijman, H.; Spek, A. L.; Reedijk, J. Inorg. Chim. Acta 2004, 357, 3697-3702.

(16) de Hoog, P.; Pachon, L. D.; Gamez, P.; Lutz, M.; Spek, A. L.; Reedijk J. Dalton Trans. 2004, 2614-2615.

(17) The copper complexes prepared in situ by reaction of $\mathrm{CuCl}_{2}$ with an equimolar amount of Hpyramol or Hpyrimol show similar cleavage activities.

(18) Pogozelski, W. K.; Tullius, T. D. Chem. Rev. 1998, 98, 1089-1107.

(19) Appropriate solutions of DNA and complex were flushed with argon for $20 \mathrm{~min}$ and then mixed in a vial. This vial was tightly sealed under argon and incubated for the required time.

(20) Sreedhara, A.; Freed, J. D.; Cowan, J. A. J. Am. Chem. Soc. 2000, 122, 8814-8824.

(21) The $k_{\mathrm{obs}}$ values were calculated for the saturation kinetics observed under true Michaelis-Menten conditions and using the equation $y=\left(y_{0}-\right.$ const $)$ $\exp \left(-k_{\mathrm{obs}} t\right)+$ const, where $y$ is the percentage of a specific form of DNA at the time $t$, and const is the percentage of uncleaved DNA; $k_{\mathrm{obs}}$ is the cleavage rate or apparent rate constant, and $y_{0}$ is the initial percentage of a form of DNA [Sreedhara, A.; Freed, J. D.; Cowan, J. A. J. Am. Chem. Soc. 2000, 122, 8814-8824].

(22) Komeda, S.; Lutz, M.; Spek, A. L.; Chikuma, M.; Reedijk, J. Inorg. Chem 2000, 39, 4230-4236.

(23) Komeda, S.; Lutz, M.; Spek, A. L.; Yamanaka, Y.; Sato, T.; Chikuma M.; Reedijk, J. J. Am. Chem. Soc. 2002, 124, 4738-4746.

(24) Lamour, E.; Routier, S.; Bernier, J. L.; Catteau, J. P.; Bailly, C.; Vezin, H. J. Am. Chem. Soc. 1999, 121, 1862-1869.

(25) Singh, U. S.; Scannell, R. T.; An, H.; Carter, B. J.; Hecht, S. M. J. Am Chem. Soc. 1995, 117, 12691-12699.

(26) Jin, Y.; Cowan, J. A. J. Am. Chem. Soc. 2005, 127, 8408-8415.

JA056970+ 